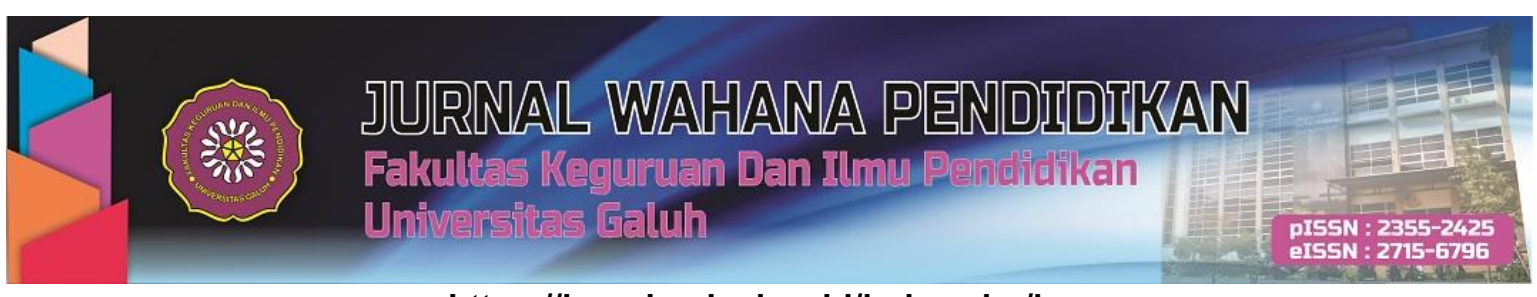

https://jurnal.unigal.ac.id/index.php/jwp

\title{
MENINGKATKAN PEMAHAMAN KONSEP MATEMATIS MATERI OPERASI HITUNG BILANGAN BULAT MELALUI METODE DEMONSTRASI DENGAN MEDIA
}

\author{
Cik Risnayati \\ SD Negeri 1 Tanjung Raya Sukau, Kabupaten Lampung Barat, Indonesia \\ Email: risnayaticik@gamail.com
}

\begin{abstract}
Based on the results of daily tests of mathematics subjects on the operation of counting integers, it shows the students' low level of mastery of the material. The factor of this is the learning process which is dominated by the teacher, tends to be lecture and the teacher only provides examples of questions. One way to improve students' understanding of concepts is to use demonstration methods with media. The purpose of this study was to improve understanding of the mathematical concept of integer arithmetic operations involving negative numbers in grade $\mathrm{Vl}$ elementary school students using demonstration methods with media. This research is a classroom action research consisting of two cycles. The subjects of this study were the sixth grade students of SD Negeri 1 Tanjung Raya, totaling 36 students. Data collection techniques, namely by observation and tests. The results showed that the learning outcomes had increased, namely the results of the pre-cycle test $47 \%$, the first cycle $64 \%$ and the second cycle to $92 \%$. In addition, the activeness of students in participating in learning activities also increases. Thus it can be concluded that the use of the demonstration method is proven to improve the understanding of the mathematical concepts of the integer arithmetic operation material in students.
\end{abstract}

Key words: integers, demonstration method, conceptual understanding.

\section{ABSTRAK}

Berdasarkan hasil ulangan harian mata pelajaran matematika tentang operasi hitung bilangan bulat menunjukkan rendahnya tingkat penguasaan materi siswa. Faktor terjadinya hal tersebut adalah proses pembelajaran yang didominasi oleh guru, cendrung bersifat ceramah dan guru hanya memberikan contoh-contoh soal. Salah satu cara untuk meningkatkan pemahaman konsep siswa adalah menggunakan metode demonstrasi dengan media. Tujuan penelitian ini adalah untuk meningkatkan pemahaman konsep matematika materi operasi hitung bilangan bulat yang melibatkan bilangan negatif pada siswa SD kelas VI menggunakan metode demonstrasi dengan media. Penelitian ini adalah penelitian tindakan kelas yang terdiri dari dua siklus. Subjek penelitian ini adalah siswa kelas VI SD Negeri 1 Tanjung Raya yang berjumlah 36 orang siswa. Teknik pengumpulan data yaitu dengan observasi dan tes. Hasil penelitian menunjukkan bahwa hasil pembelajaran mengalami peningkatan yaitu hasil tes prasiklus $47 \%$, siklus pertama $64 \%$ dan siklus dua menjadi $92 \%$. Selain itu keaktifan siswa dalam mengikuti kegitan belajar juga meningkat. Dengan demikian dapat disimpulkan bahwa penggunaan metode demonstrasi terbukti dapat meningkatkan pemahaman konsep matematika materi operasi hitung bilangan bulat pada siswa.

Kata Kunci : bilangan bulat, metode demonstrasi, pemahaman konsep.

Cara sitasi:

Risnayati, C. (2021). Meningkatkan Pemahaman Konsep Matematika Materi Operasi Hitung Bilangan Bulat melalui Metode Demonstrasi dengan Media. Jurnal Wahana Pendidikan, 8 (1), 91- 102. 


\section{PENDAHULUAN}

Pelajaran matematika merupakan salah satu pelajaran wajib untuk membekali siswa dengan kemampuan berpikir logis, analistis, sistematis, kritis, dan kreatif. Matematika juga merupakan ilmu yang berkembang pesat, baik materi dan kegunaannya. Sehingga dari setiap jenjang pendidikan dituntut untuk memahami matematika.

Ruang lingkup pelajaran matematika mencangkup beberapa kompetensi dasar yang harus dikuasai siswa, meliputi: bilangan, geometri, pengukuran dan pengolahan data. Berdasarkan standar isi kurikulum 2013 (K 13) khususnya kelas VI SD terdapat kompetensi dasar 3.1 yaitu menjelaskan dan melakukan operasi penjumlahan, pengurangan, perkalian dan pembagian yang melibatkan bilangan bulat negatif. Menurut Russeffendi ( Nurhaeni, et. al. 2019) alasan bilangan bulat diajarkan kepada siswa SD yaitu:

1) dalam kehidupan sehari-hari banyak keadaan yang memerlukan konsep bilangan bulat misalnya untung rugi, bergerak ke kanan dan ke kiri, maju mundur, di atas permukaan tanah di bawah permukaan tanah, menang kalah dalam permainan, dibawah nol derajat dan sebagainya, 2) agar penggunaan dari operasi hitung,,+- :, dan $\mathrm{x}$ lebih luas dan dalam, 3) supaya ada kaitannya dengan pelajaran ditingkat yang lebih tinggi, 4) agar siswa berkenalan dengan bilangan yang akan diberikan ditingkat yang lebih tinggi, 5) konsep bilangan bulat dapat dipahami anak asal penyampaiannya sesuai dengan kemampuan.

Materi operasi hitung bilangan bulat yang melibatkan bilangan negatif merupakan materi yang bersifat abstrak. Padahal siswa SD masih berada pada tahap operasional konkret yaitu pada usia 7-12 tahun, sesuai dengan pernyataan Piaget (Wahyuningtyas \& Iskandar, 2016). Tahap operasional konkret yaitu tahap dimana siswa menghubungkan segala sesuatu dengan yang konkret, sehingga akan susah memahami sesuatu yang bersifat abstrak. Untuk mengkonkretkannya perlu media dan metode yang tepat. Sejalan dengan pendapat Wildaniati (2016) bahwa penggunaan media dalam pembelajaran matematika sangat berarti, karena matematika yang sifatnya abstrak dan siswa SD yang masih cendrung berpikir konkrit. Oleh karena itu dalam pembelajraran matematika perlu digunakan alat peraga untuk lebih mengkonkritkan ide-ide dan konsep-konsep yang sifatnya abstrak. Dengan menggunakan alat peraga dalam pembelajaran matematika, berarti memberi pengalaman belajar pada siswa mulai dari suatu yang konkrit menuju suatu yang abstrak

Menurut Muhsetyo dkk (Eliana, 2016) mengenalkan konsep operasi hitung bilangan bulat dilakukan dengan 3 tahap. Pada tahap pertama terdapat 2 model peragaan yang dapat dikembangkan, yaitu menggunakan pendekatan himpunan (menggunakan alat peraga manikmanik), sedangkan model yang ke-dua menggunakan pendekatan hukum kekelan panjang (menggunakan balok garis bilangan atau pita garis bilangan atau tangga garis bilangan). Pada tahap kedua, proses pengerjaan operasi hitung diarahkan menggunakan garis bilangan dan pada tahap ketiga kepada siswa baru dikenalkan konsep-konsep operasi hitung yang bersifat abstrak.

Pengenalan materi operasi hitung bilangan bulat tentu terjadi pada saat proses pembelajaran berlangsung. Menurut Wardani (2019) pada hakekatnya pembelajaran (belajar dan mengajar) merupakan proses komunikasi antara guru dan siswa. Sebagai komunikan pada proses pembelajaran adalah siswa sedangkan komunikatornya adalah guru dan siswa. Jika sekelompok siswa menjadi komunikator terhadap siswa yang lainnya dan guru sebagai fasilitator, maka akan terjadi proses interaksi dengan pembelajaran yang tinggi. Seorang guru harus menyadari bahwa proses komunikasi tidak selalu berjalan dengan lancar, bahkan proses komunikasi dapat menimbulkan kebingungan, salah pengertian, atau bahkan salah konsep. Kesalahan komunikasi seorang guru akan dirasakan siswanya sebagai penghambat pembelajaran. Kesalahan komunikasi dalam pembelajaran dapat terjadi karena faktor dari guru, siswa atau guru dan siswa. Untuk menghindari kemungkinan terjadinya salah komunikasi maka diperlukan alat bantu (sarana) yang dapat membantu proses komunikasi. Sarana tersebut selanjutnya disebut media. 
Berdasarkan hasil ulangan harian mata pelajaran matematika tentang operasi hitung bilangan bulat menunjukkan rendahnya tingkat penguasaan materi. Dari 36 siswa di kelas VI hanya $17(47 \%)$ siswa yang nilainya mencapai $\geq 65$ sesuai dengan KKM mata pelajaran matematika di SD Negeri 1 Tanjung Raya. Faktor penyebab siswa kurang menguasai materi pelajaran adalah guru lebih terlibat aktif dalam pembelajaran sebagai pemberi pengetahuan kepada siswa, kurang komunikatif, cendrung bersifat ceramah, siswa kurang terlibat aktif, guru hanya memberikan contohcontoh soal yang bersifat abstrak sehingga siswa tidak dapat bernalar, berkomunikasi serta memecahkan masalah yang dituntut dalam kurikulum.

Salah satu cara untuk meningkatkan pemahaman konsep siswa tentang materi operasi hitung bilangan bulat adalah menggunakan metode demonstrasi dengan media. Metode demonstrasi merupakan penyajian pelajaran dengan memperagakan atau mempertunjukkan kepada siswa tentang suatu proses, situasi benda tertentu, baik sebenarnya atau sekedar tiruan. Sebagai metode penyajian, demonstrasi tidak terlepas dari penjelasan secara lisan oleh guru. Walaupun dalam proses demonstrasi siswa hanya sekedar memperhatikan, akan tetapi demonstrasi dapat menyajikan bahan pelajaran lebih konkrit. Metode ini cukup efektif membantu siswa memahami suatu konsep berdasarkan hasil pengamatan (Aprinawati, 2017).

Menurut Muhibbin (Shoimin, 2014) metode demonstrasi adalah metode mengajar dengan memperagakan barang, kejadian, aturan dan urutan melakukan sesuatu kegiatan, baik langsung maupun menggunakan media pelajaran yang relevan dengan materi pelajaran yang sedang disajikan. Metode demonstrasi merupakan format interaksi belajar-mengajar yang sengaja mempertunjukkan atau memperagakan tindakan, proses, atau prosedur yang dilakukan oleh guru atau orang lain kepada seluruh siswa atau sebagian siswa. Dengan batasan metode demonstrasi ini, menunjukkan adanya tuntutan kepada guru untuk merencanakan penerapannya, memperjelas demonstrasi peragaan maupun pernyataan lisan atau visual, dan menyediakan peralatan yang diperlukan.

Berdasarkan papara dan permasalahan tersebut maka peneliti berupaya melakukan cara yang paling efektif dalam memperkenalkan konsep matematika kepada pesrta didik, untuk meningkatkan pemahaman konsep matematika materi operasi hitung bilangan bulat pada siswa melalui metode demonstrasi dengan media. Oleh sebab itu tujuan penelitian ini adalah untuk meningkatkan pemahaman konsep matematika materi operasi hitung bilangan bulat yang melibatkan bilangan negatif pada siswa SD kelas VI menggunakan metode demonstrasi dengan media.

\section{METODE PENELITIAN}

Jenis penelitian yang digunakan adalah penelitian tindakan kelas (Classroom Action Research), yaitu bentuk penelitian yang dilakukan guru di kelas atau di sekolah tempat mengajar melalui refleksi diri, dengan tujuan memperbaiki kualitas proses pembelajaran di kelas, sehingga hasil belajar siswa dapat ditingkatkan yang dilaksanakan dalam bentuk proses pengkajian daur/siklus. Proses pengkajian terdiri dari 4 tahap yaitu perencanaan, tindakan, observasi dan refleksi.

Subjek penelitian adalah seluruh siswa kelas VI SDN 1 Tanjung Raya Kecamatan Sukau Kabupaten Lampung Barat, yang berjumlah 36 siswa, terdiri dari 19 siswa perempuan dan 17 siswa laki-laki. Penelitian ini menggunakan 2 data, yaitu data pemantau tindakan (proses) dan data penelitian (hasil). Data yang diperoleh dari kesesuaian pelaksanaan dengan rencana tindakan merupakan data pemantau tindakan atau observasi. Sementara data yang diperoleh dari hasil tes kemampuan siswa yang merupakan skor hasil belajar matematika materi operasi hitung bilangan adalah data penelitian. Keberhasilan tindakan ditentukan oleh besarnya prosentase kenaikan minimal tindakan dan pencapaian KKM. Adapun besarnya prosentase kenaikan tindakan yang diharapkan dari persentase ketuntasan hasil ulangan harian adalah $85 \%-47 \%=38 \%$ dan besarnya Kriteria Ketuntasan Minimal (KKM) adalah 65. 
Teknik pengumpulan data dalam penelitian ini dilakukan melalui teknik observasi, tes, dan dokumentasi. Teknik-teknik ini dilakukan sesuai dengan data yang diperlukan dalam penelitian. Observasi dilakukan untuk memperoleh data tentang proses pembelajaran. Instrumen observasi berupa kolom dimensi pengamatan yang berisi pelaksanaan pembelajaran, aspek pengamatan yang berisi kegiatan guru dan siswa, serta kolom keterangan yang berisi ya dan tidak yang harus diisi dengan tanda chek list $(\sqrt{ }$ ) oleh teman sejawat (observer). Hasil belajar siswa berupa skor yang diperoleh melalui tes. Hasil yang diperoleh dimasukkan dalam lembar penilaian untuk selanjutnya dianalisis.

Analisis data penelitian dilakukan dengan menguji hipotetis tindakan, yaitu dengan menggunakan perbedaan rata-rata skor siswa sebelum memperoleh tindakan dan setelah memperoleh tindakan. Analisis data ini dilakukan dalam setiap akhir siklus dengan menghitung ratarata skor siswa dan persentase kenaikan dengan memperhatikan kriteria keberhasilan yang telah ditetapkan. Teknik analisis data yang digunakan bertujuan untuk mengetahui pengaruh pemberian tindakan menggunakan metode demonstrasi dengan media pada siswa kelas VI SD dalam upaya meningkatkan pemahaman konsep matematika materi operasi hitung bilangan bulat.

\section{Deskripsi Per Siklus}

1. Siklus I

a. Perencanaan Tindakan

Pada tahap perencanaan peneliti membuat rencana pelaksanaan pembelajaran dan lembar tugas siswa. Sedangkan instrumen pengumpulan data yang digunakan adalah lembar observasi aktifitas guru dan siswa dalam pembelajaran. Materi pembelajaran yang dilaksanakan pada siklus I adalah operasi hitung bilangan bulat yang melibatkan bilangan negatif dengan menerapkan metode demonstrasi. Penilaian terhadap pembelajaran disiklus I ini adalah dengan melaksanakan tes di akhir pembelajaran pertemuan 3. Tes tersebut untuk menentukan skor akhir yang diperoleh pada siklus I, dan berguna untuk melihat keberhasilan dari siklus I

b. Pelaksanaan Tindakan

Kegiatan yang dilakukan dalam tahap pelaksanaan pada siklus pertama ini adalah mengelola kelas, absensi kehadiran siswa dan melaksanakan pembelajaran. Dalam tiga kali pertemuan siklus pertama pelaksanaan pembelajaran dengan menggunakan model pembelajaran demonstrasi dengan kegiatan sebagai berikut:

1. Memberikan penjelasan tentang topik yang akan didemonstrasikan.

2. Pelaksanaan demonstrasi bersamaan dengan perhatian dan peniruan dari siswa.

3. Diskusi, pada tahap ini siswa menggunakan media garis bilangan, mobil dan katak mainan untuk menyelesaikan kegiatan yang ada pada LKS. Siswa memperagakan sendiri media kemudian menuliskan pergerakannya dan memperoleh hasil akhir. Guru berkeliling melihat pekerjaan siswa dan membantu mengarahkan siswa apabila mengalami kesulitan. Lalu siswa mempresentasikan hasil diskusi pada kegiatan yang telah dikerjakan dengan memperagakan menggunakan media.

4. Tanya jawab, dan latihan

5. Penguatan atas latihan, tanya jawab dan hasil diskusi terhadap demonstrasi.

6. Kesimpulan.

\section{c. Observasi}

Kegiatan yang dilakukan dalam tahap observasi/pengamatan pada siklus pertama ini adalah pada waktu pelaksanaan pembelajaran observer ikut masuk ke dalam kelas. Observer duduk di belakang siswa atau berkeliling kelas dengan membawa lembar pengamatan untuk mengamati aktivitas guru waktu melaksakan pembelajaran, dan lembar pengamatan untuk mengamati kegiatan siswa dalam kelompok. Hal-hal yang dilakukan oleh observer adalah mengamati aktifitas siswa dalam menjawab soal, aktifitas siswa dalam kerja kelompok mengerjakan LKS, 
aktifitas siswa dalam menyampaikan hasil kerja kelompok, aktifitas guru dalam proses pembelajaran.

d. Refleksi

Kegiatan pada tahap refleksi adalah mengumpulkan data berupa nilai ulangan harian, nilai hasil tes dan hasil observasi pada pelaksanaan PTK. Selanjutnya dilaksanakan pencermatan, pengkajian, analisis, sistesis dan penilaian terhadap hasil observasi terhadap tindakan yang telah dilakukan. Jika terdapat masalah dari proses refleksi pertama, maka akan dilakukan pengulangan tindakan perbaikan pembelajaran pada siklus II. Kegiatan yang dilakukan dalam tahap refleksi siklus I ini adalah: mancatat hasil pengamatan, mengevaluasi hasil pengamatan, menganalisis hasil tes dan memperbaiki kelemahan untuk siklus berikutnya.

2. Siklus II

a. Perencanaan

Pada tahap perencanaan pada siklus II ini peneliti kembali menyusun rencana pembelajaran, memadukan hasil refleksi siklus I agar siklus II lebih efektif, menyiapkan media pembelajaran, menyiapkan LKS dan tes tulis.

b. Pelaksanaan Tindakan

Pelaksanaan pembelajaran pada siklus II, urutan pelaksaan masih sama, yaitu tiga kali pertemuan, namun perbedaannya adalah adanya perbaikan tindakan pada kelemahan yang ditemukan pada siklus I.

c. Observasi

Kegiatan yang dilakukan dalam tahap observasi pada siklus II ini sama dengan siklus I.

d. Refleksi

Kegiatan pada tahap ini adalah menganalisis hasil kegiatan siklus I dan II dengan melihat dan mengkaji ketercapaian pembelajaran melalui metode pembelajaran demonstrasi menggunakan media dalam memahami konsep operasi hitung bilangan bulat yang melibatkan bilangan negatif, sehingga dapat diketahui perbandingan hasil pelaksanaan tindakan siklus I dengan siklus II. Kegiatan yang dilakukan dalam tahap refleksi siklus II ini adalah: mancatat hasil pengamatan, mengevaluasi hasil pengamatan, menganalisis hasil tes dan menyusun laporan.

\section{HASIL DAN PEMBAHASAN}

Kondisi awal sebelum melaksanakan penelitian dengan menggunakan metode demonstrasi diketahui bahwa hasil ulangan harian siswa pada materi operasi hitung bilangan bulat masih rendah. Persentase ketuntasan siswa adalah $47 \%$ karena dari 36 siswa di kelas VI hanya 17 siswa yang nilainya mencapai nilai 65 ke atas, sesuai dengan KKM pelajaran matematika di SDN 1 Tanjung Raya, dengan nilai rata-rata 55 , maka pembelajaran dikatakan belum berhasi, sehingga perlu dilakukan perbaikan.

Berdasarkan data tes hasil belajar siklus I, baru 64\% siswa yang mencapai nilai (KKM) dengan nilai rata-rata 70,16. Dari hasil observasi peran aktif siswa masih belum terlihat selama pembelajaran karena siswa merasa bingung dalam menentukan arah langkah mobil dan katak dalam mendemonstrasikan media ketika kerja kelompok, trutama untuk pengurangan dan pembagian bilangan bulat, sehingga siswa masih kesulitan untuk menetukan hasil akhir bilangan bertanda positif atau negatif. Siswa kurang berani menjawab pertanyaan guru, hanya siswa tertentu yang terlihat aktif. Dapat dikatakan pembelajaran pada siklus I belum berhasil karena menurut Depdiknas (Pauziah, 2017) kualitas pembelajaran dapat dilihat dari segi proses pembelajaran dan dari segi hasil. Dari segi proses pembelajaran dikatakan berhasil apabila seluruhnya atau setidak tidaknya sebagaian besar $(85 \%)$ peserta didik terlibat secara aktif baik fisik, mental maupun sosial dalam proses pembelajaran di samping menunjukkan kegairahan belajar tinggi, semangat belajar yang besar dan rasa percaya diri yang tinggi. Sedangkan dari segi hasil, pembelajaran dikatakan berhasil apabila peserta didik yang mencapai nilai KKM setidak-tidaknya $85 \%$. 
Setelah selesai pembelajaran siklus II, siswa diberi tes untuk menguji pemahaman siswa tentang operasi hitung bilangan bulat. Pemahaman yang mendalam terhadap materi membuat siswa mampu menyelesaikan sosl-soal dengan baik, dengan ketuntasan sebesar $92 \%$, artinya telah terjadi kenaikan 45\% siswa yang mencapai nilai KKM dari pratindakan, dengan nilai rata-rata 89,20. Data ini menunjukkan bahwa hasil intervensi tindakan telah melebihi prosentase kenaikan minimal yang ditetapkan sebesar $38 \%$. Ditinjau dari keaktifan selama proses pembelajaran dan pada saat diskusi klasikal, peran aktif siswa semakin meningkat, siswa tidak segan-segan dalam menjawab pertanyaan guru, dan berani mengungkapkan pendapatnya. Siswa merasa nyaman dan tidak tegang dalam mengikuti proses pembelajaran. Siswa lebih mudah memahami materi yang sedang dipelajari. Berdasarkan hasil pembelajaran siklus II indikator keberhasilan telah terpenuhi.

Perbandingan hasil belajar dari pratindakan pembelajaran berdasarkan hasil ulangan harian, siklus I dan siklus II pelajaran matematika tentang operasi hitung bilangan bulat dengan menggunakan metode demonstrasi adalah persentase ketuntasan siswa pada pratindakan $47 \%$ dengan nilai rata-rata 55 pada siklus I meningkat menjadi $64 \%$ dengan rata-rata 70,16 , kemudian pada siklus II meningkat menjadi $92 \%$ dengan rata-rata 89,20 . Peningkatan hasil belajar dari prasiklus, siklus I ke siklus II dapat dilihat pada Tabel 1.

Tabel 1.

Perbandingan Hasil Belajar Siswa Pratindakan, Siklus I dan Siklus II

\begin{tabular}{lcccc}
\hline No & Keterangan & Pratindakan & Siklus I & Siklus II \\
\hline 1 & Nilai rata-rata & 55 & 70,16 & 89,20 \\
2 & Persentase ketuntasan & $47 \%$ & $64 \%$ & $92 \%$ \\
\hline
\end{tabular}

Berdasarkan Tabel 1, pada siklus II terlihat bahwa 92\% siswa telah mampu memahami materi operasi hitung bilangan bulat melalui metode demonstrasi dan mengalami peningkatan yang sangat signifikan dari pratindakan, ke siklus 1 dan ke siklus 2. Hal tersebut membuktikan bahwa penggunaan metode demonstrasi dengan media sangat tepat untuk meningkatkan kemampuan siswa khususnya pada materi operasi hitung bilangan bulat. Untuk lebih jelasnya adanya peningkatan tersebut disajikan pada Gambar 1.

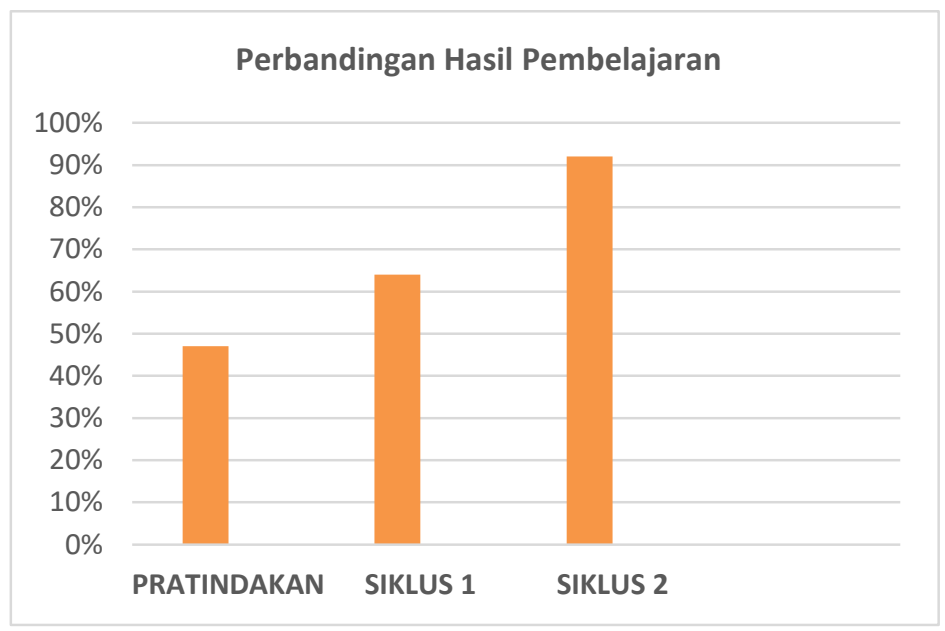

Gambar 1. Peningkatan Hasil Belajar Siswa

Berdasarkan Gambar 1, terlihat peningkatan yang signifikan mulai dari pra siklus (47\%), kemudian pada siklus 1 meningkat menjadi $64 \%$ dan siklus 2 meningkat menjadi $92 \%$.

\section{Penerapan Metode Demonstrasi dalam Meningkatkan Pemahaman Siswa}

Sebelum pembelajaran dilaksanakan, selain membuat Rencana Pelaksanaan Pembelajaran (RPP), seorang guru harus menentukan konsep materi yang akan dipelajari siswa, mencari dan 
merumuskan masalah yang sesuai dengan konsep tersebut, serta merencanakan strategi pembelajaran yang cocok dan menyiapkan media yang dibutuhkan. Berikut disajikan persiapan dari materi dan media:

1. Pengertian bilangan bulat

Menurut Purnomo (2013) bilangan bulat merupakan perluasan dari bilangan cacah. Himpunan bilangan bulat terdiri atas himpunan bilangan asli, yaitu $\{1,2,3,4, \ldots\}$ yang selanjutnya disebut bilangan bulat positif, bilangan nol $\{0\}$, dan himpunan lawan dari bilangan asli, yaitu $\{-1,-2,-3,-4, \ldots\}$ yang selanjutnya diebut bilangan bulat negatif.

2. Penggunaan media pada operasi hitung bilangan bulat

1) Balok kayu garis bilangan, media sama seperti garis bilangan biasa, di dalamnya memuat bilangan bulat positif, bilangan bulat negatif dan nol, yang berfungsi sebagai lintasan ketika mendemonstrasikan operasi hitung bilangan bulat.

2) Spidol berwarna merah dan biru, untuk membuat anak panah sesuai tempat mobil mainan berhenti. Spidol merah digunakan untuk bilangan negatif sedangkan yang biru untuk bilangan positif.

3) Mobil mainan digunakan untuk mendemonstrasiakan penjumlahan dan pengurangan bilangan bulat, sebab gerakan yang dibutuhkan adalah maju atau mundur untuk penjumlahan, sedangkan maju, berbalik arah dan mundur untuk pengurangan. Jadi yang paling tepat dalam kehidupan sehari-hari yang gerakannya seperti itu adalah mobil. Mobil maianan mempunyai sisi muka dan sisi belakang agar siswa dapat membedakan arah maju dan mundur pada mobil tersebut.

4) Katak mainan digunakan untuk mendemonstrasiakan perkalian dan pembagian bilangan bulat sebab gerakan yang dibutuhkan adalah lompatan-lompatan. Jadi yang paling tepat dalam kehidupan sehari-hari yang gerakannya melompat adalah katak.

Intervensi tindakan meningkatkan pemahaman konsep operasi hitung bilangan bulat dilaksanakan dalam 2 siklus dan setiap siklus terdiri dari 3 kali pertemuan dengan waktu 2 × 35 menit setiap pertemuan dilaksanakan pada jam efektif. Langkah-langkah kegiatan pada setiap siklus secara umum adalah sama. Perbedaannya pada siklus II waktu yang digunakan lebih banyak membahas materi pengurangan dan pembagian yang melibatkan bilangan negatif, karena seperti yang telah dijelaskan pada hasil observasi yang dilakukan teman sejawat pada siklus I, siswa masih kebingungan menentukan arah dari media ketika melakukan demonstrasi dan kesulitan untuk menentukan hasil akhir bilangan bertanda positif atau negatif, serta setelah guru melakukan analisis hasil tes siswa, jawaban yang banyak kesalahannya ada pada soal tentang pengurangan dan pembagian bilangan bulat tersebut.

Secara umum langkah-langkah dalam pembelajaran, dalam hal ini untuk meningkatkan pemahaman konsep pada pelajaran matematika dengan materi operasi hitung bilangan bulat yang melibatkan bilangan negatif adalah sama, seperti yang telah dipaparkan pada pelaksanaan siklus I. Perbedaannya hanya pada langkah-langkah demonstrasi pada masing-masing materi operasi hitung. Adapun proses demonstrasi operasi hitung bilangan bulat pada tiap-tiap materi adalah sebagai berikut:

\section{Materi: Penjumlahan Bilangan Bulat}

Mendemonstrasikan cara menjumlahkan bilangan bulat untuk membimbing siswa memahami konsep dengan media mobil maianan, spidol berwarna biru dan merah pada balok garis bilangan. Menurut Gunanto \& Dhesy (2018) langakah-langkahnya adalah seperti berikut:

1. Letakkan selalu posisi awal mobil pada titik nol, menghadap arah positif $(+)$

2. Jika bilangan pertama positif $(+)$ maka mobil maju, bila negatif (-) mobil mundur

3. Langkah berikutnya bila bilangan penjumlah positif $(+)$ maka mobil maju, bila negative $(-)$ mobil mundur dari langkah pertama, hasilnya adalah titik akhir langkah kedua mobil. Serta menuliskan anak panah pada tiap mobil berhenti. 
Contoh :

a. $-6+8=\ldots$

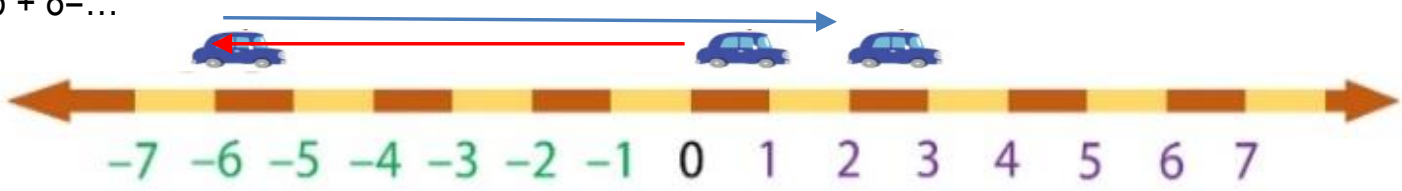

Jadi, $-6+8=2$

b. $-3+(-2)=\ldots$

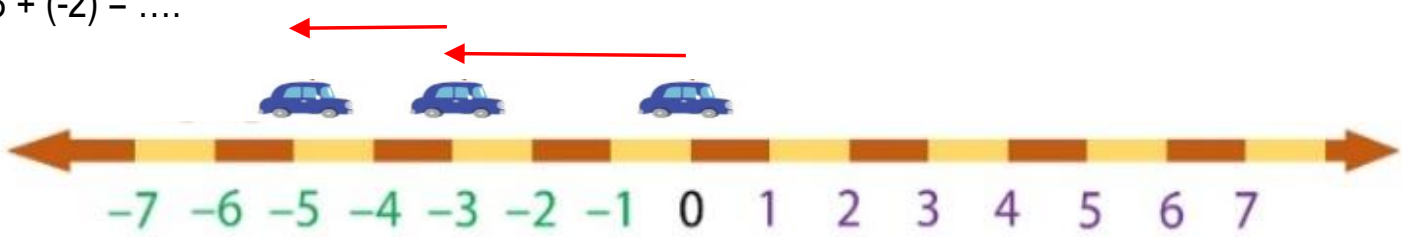

Jadi, $-3+(-2)=-5$

Kesimpulan setelah mendemonstrasikan cara menjumlahkan bilangan bulat pada balok garis bilangan yaitu menanamkan konsep ke siswa bahwa sifat-sifat operasi penjumlahan bilangan bulat adalah:

1. Penjumlahan dua bilangan yang bertanda sama, hasilnya merupakan penjumlahan kedua bilangan itu dengan tanda sama dengan bilangan yang dijumlahkan

Contoh : a. $8+3=11$

$$
\text { b. }-8+-3=-11
$$

2. Penjumlahan dua bilangan yang bertanda berbeda, hasilnya merupakan pengurangan bilangan yang besar dengan bilangan yang kecil, tandanya sama dengan bilangan yang besar.

Contoh : a. $-8+3=-5$

$$
\text { b. } 8+-3=5
$$

\section{Materi: Pengurangan Bilangan Bulat}

Mendemonstrasikan pengurangan bilangan bulat menggunakan balok garis bilangan dengan media mobil mainan, spidol warna merah dan biru dengan tujuan dapat membimbing siswa memahami konsep pengurangan bilangan bulat menurut Gunanto \& Dhesy (2018) langakahlangakahnya seperti berikut :

1. Letakkan selalu posisi awal mobil pada titik nol menghadap arah positif $(+)$

2. Jika bilangan pertama positif $(+)$ maka mobil maju, bila negatif $(-)$ mundur.

3. Langkah berikutnya karena pengurangan maka balikkan arah mobil, bila bilangan pengurang positif $(+)$ maka mobil maju, bila negative $(-)$ mobil mundur, hasilnya adalah titik akhir mobil. Sambil menuliskan letak anak panah sesuai dengan tempat mobil berhenti.

Contoh :

a. $-5-2=\ldots$.

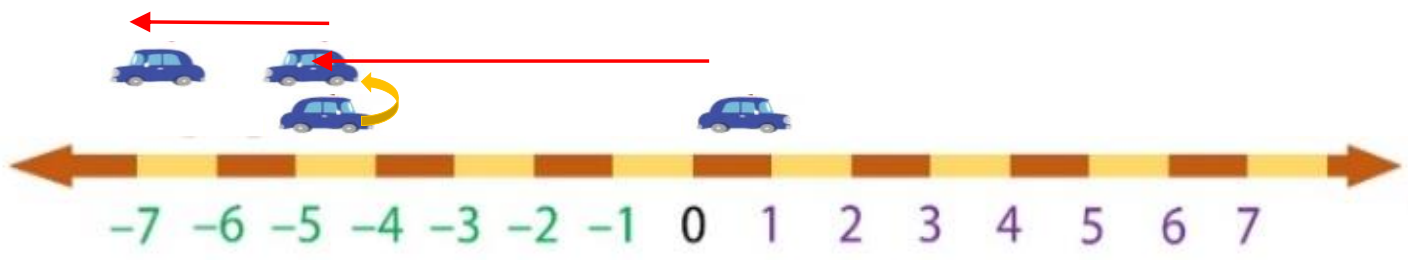

Jadi, $-5-2=-7$

b. $4-(-3)=\ldots$.

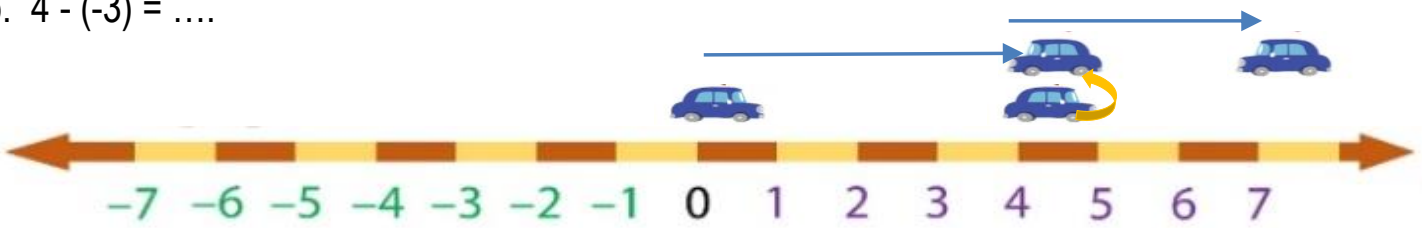

Jadi, $4-(-3)=7$ 
Kesimpulan setelah mendemonstrasikan cara mengurangkan bilangan bulat pada balok garis bilangan yaitu menanamkan konsep ke siswa bahwa mengurangi suatu bilangan bulat sama artinya dengan menambah dengan lawan pengurangnya.

Contoh : a. $-5-2=-7 \longrightarrow=-5+(-2)=-7$

b. $4-(-3)=7 \longrightarrow=4+3=7$

\section{Materi: Mengalikan Bilangan Bulat Negatif}

1. Guru mengingatkan kembali tentang konsep perkalian bilangan cacah yang telah mereka pelajari di kelas sebelumnya. Contoh : $4 \times 3=3+3+3+3=12$

2. Mendemonstrasikan perkalian bilangan bulat menggunakan garis bilangan dengan tujuan menjelaskan kepada siswa konsep perkalian bilangan bulat negatif menggunakan peraga balok garis bilangan dan model katak mainan dengan konsep seperti di atas. Langkah-langkahnya menurut Tantowi (2013) adalah:

a) Selalu letakkan katak di titik nol.

b) Perhatikan bilangan yang disebelah kanan tanda kali (x), jika positif katak menghadap ke kanan (positif), jika negatif katak mengarah ke kiri (negatif).

c) Perhatikan bilangan yang disebelah kiri tanda kali (x), jika positif katak maju, jika negative katak mundur.

d) Bilangan yang merupakan hasil adalah tempat katak berhenti

Contoh :

a. $-3 \times 2=\ldots$.

1. Letakkan katak pada titik nol menghadap arah positif (karena 2 adalah positif)

2. Katak mundur 3 langkah (karena 3 bernilai negatif), setiap langkah 2 x loncatan

3. Hasilnya adalah tempat katak berhenti, seperti gambar berikut

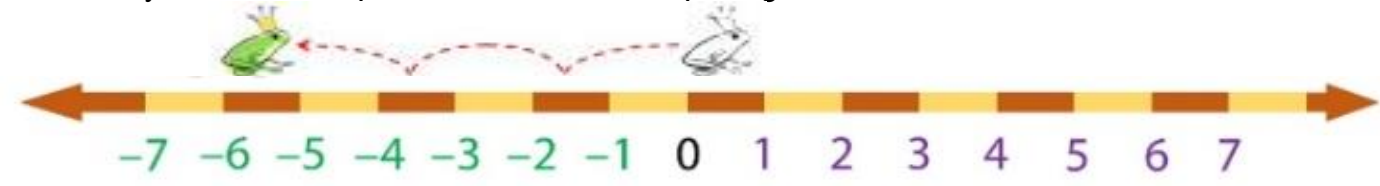

Jadi, $-3 \times 2=-6$

b. $-3 \times(-2)=\ldots$

1. Letakkan katak pada titik nol menghadap arah negatif (karena 2 adalah negatif)

2. Katak mundur 3 langkah (karena 3 bernilai negatif), setiap langkah $2 \times$ loncatan

3. Hasilnya adalah tempat katak berhenti, seperti gambar berikut

$$
\begin{array}{lllllllllllllll}
-7 & -6 & -5 & -4 & -3 & -2 & -1 & 0 & 1 & 2 & 3 & 4 & 5 & 6 & 7
\end{array}
$$

Jadi, $-3 \times(-2)=6$

Kesimpulan setelah mendemonstrasikan cara mengalikan bilangan bulat pada balok garis bilangan yaitu menanamkan konsep ke siswa bahwa:

$$
\begin{aligned}
& \text { Hasil perkalian dua bilangan bulat } \\
& \text { bertanda sama = bilangan positif } \\
& \text { - positif } x \text { positif = positif } \\
& \text { - negatif } x \text { negatif = positif }
\end{aligned}
$$

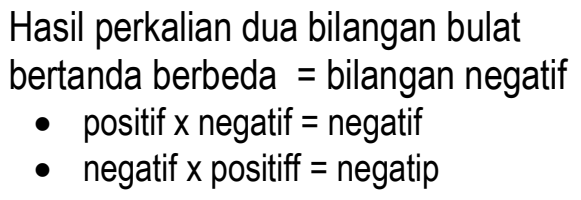

\section{Materi: pembagian bilangan bulat}

1. Guru mengingatkan kembali tentang konsep pembagian bilangan cacah yang telah mereka pelajari di kelas sebelumnya, yaitu pembagian merupakan pengurangan berulang.

Contoh : $12: 3=12-3-3-3-3=4$ 
2. Mendemonstrasikan langkah-langkah pembagian bilangan bulat negatif dengan peraga balok garis bilangan dan model katak mainan dengan konsep seperti di atas. Langkah-langkahnya menurut Tantowi (2013) adalah:

a) Letakkan posisi awal katak di titik nol.

b) Perhatikan bilangan pembagi, selain untuk menentukan jumlah loncatan setiap langkah katak. Bilangan pembagi juga digunakan untuk menentukan arah katak, jika bilangan pembagi positif katak menghadap ke kanan (positif), jika negatif katak mengarah ke kiri (negatif).

c) Perhatikan bilangan yang dibagi untuk menentukan bilangan yang akan dituju.

d) Hasil pembagian ditentukan dari jumlah langkah dari nol sampai ke bilangan yang dituju.

e) Tanda hasil bilangan ditentukan oleh gerak maju atau mundur katak, jika katak maju bernilai positif dan jika katak mundur bernilai negatif.

Contoh:

a. $-6: 2=\ldots$

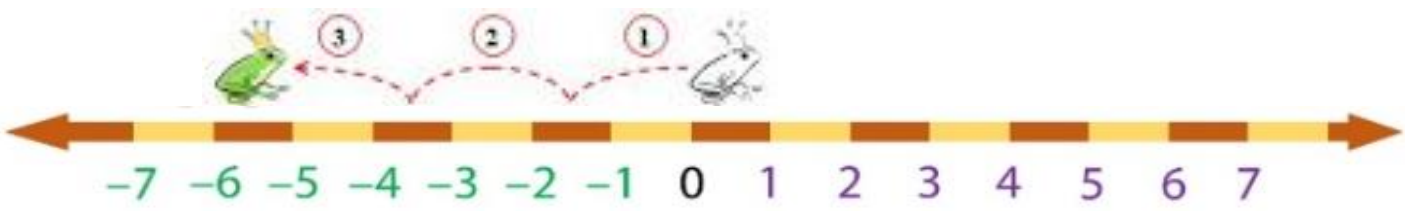

Jadi, $-6: 2=-3$

Hasil dari $-6: 2=-3$, diperoleh dari menghitung banyak langkah katak dari 0 menuju -6 yaitu 3 langkah. Langkah mundur bernilai negatif (-).

b. $-6:-2=\ldots$.

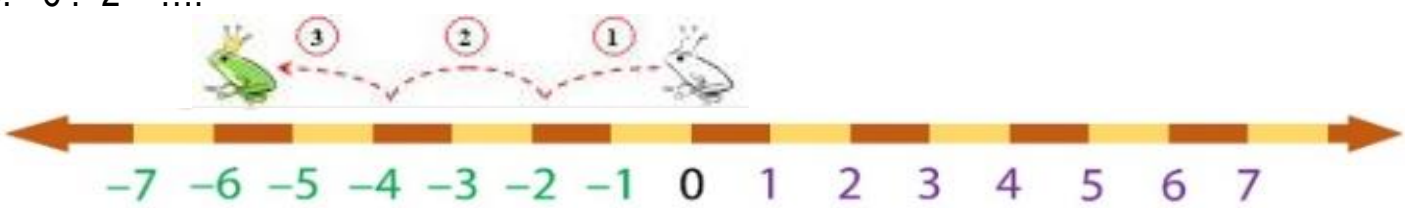

Jadi, $-6:-2=3$

Hasil dari $-6:-2=3$, diperoleh dari menghitung banyak langkah katak dari 0 menuju -6 yaitu 3 langkah. Langkah maju bernilai positif $(+)$.

Kesimpulan setelah mendemonstrasikan cara mengalikan bilangan bulat pada balok garis bilangan yaitu menanamkan konsep ke siswa bahwa:

$$
\begin{aligned}
& \text { Hasil pembagian dua bilangan bulat } \\
& \text { bertanda sama = bilangan positif } \\
& \text { - positif : positif = positif } \\
& \text { - negatif : negatif = positif }
\end{aligned}
$$

Hasil pembagian dua bilangan bulat

bertanda berbeda $=$ bilangan negatif

- positif : negatif $=$ negatif

- negatif : positiff = negatip

Tahapan yang telah dirancang secara garis besar sesuai dengan tahapan perkembangan berpikir siswa yang dinyatakan oleh Burner (Wahyuningtyas, 2015) yaitu:

1. Enaktif, pada tahap ini anak-anak belajar dengan menggunakan atau memanipulasi media secara langsung. Siswa memperagakan dan menjalan media.

2. Ikonik, pada tahap ini anak-anak mulai mengaitkan mental yang merupakan gambaran dari objek. Siswa mentranlasi pergerakan media ke dalam symbol angka pada garis bilangan di luar media.

3. Symbolic, pada tahap ini merupakan tahap memanipulasi simbol-simbol secara langsung. Siswa telah mampu menggunakan notasi untuk menyelesaikan operasi hitung bilangan bulat.

Penggunaan media mainan ini dapat membantu siswa dalam memahami konsep operasi hitung bilangan bulat yaitu siswa dapat menggambarkan operasi hitung dengan media atau garis bilangan, mengubah dari pergerakan media menjadi kalimat matematika dan kemudian siswa dapat mengerjakan operasi hitung bilangan bulat tanpa media. 
Langkah-langkah pemahaman konsep operasi hitung bilangan bulat dengan menggunakan media mobil dan katak maianan sejalan dengan Hiebert \& Carpenter (Wahyuningtyas, 2015) yaitu:

1. Pemahaman adalah generative, siswa dapat mengaitkan operasi hitung bilangan bulat dengan materi yang telah didapatkan sebelumnya, yaitu operasi hitung bilangan cacah.

2. Pemahaman memacu ingatan, penggunaan media mainan dapat membantu siswa untuk mengingat konsep operasi hitung bilangan bulat.

3. Pemahaman mengurangi banyaknya hal yang harus diingat, siswa memberikan kesimpulan terhadap materi berdasarkan kegiatan yang telah dilakukan sehingga siswa dapat mengurangi banyaknya rumus untuk diingat.

4. Pemahaman dapat meningkatkan proses perpindahan informasi, artinya siswa dapat mengaitkan materi operasi hitung bilangan bulat dalam kehidupan sehari-hari, sehingga dapat menyelesaikan soal dengan mudah.

Mengacu dari metode yang dipergunakan, maka selama proses kegiatan belajar mengajar siswa dapat memusatkan perhatiannya pada materi pelajaran yang didemonstrasikan, siswa memperoleh pengalaman yang dapat membentuk ingatan yang kuat, siswa terhindar dari kesalahan dalam mengambil suatu kesimpulan, pertanyaan-pertanyaan yang timbul dapat dijawab sendiri oleh siswa pada saat dilaksanakannya demonstrasi, apabila terjadi keraguan siswa dapat menanyakan secara langsung kepada guru, kesalahan yang terjadi dari hasil ceramah dapat diperbaiki karena langsung diberikan contoh konkretnya. Hasil penelitian ini sejalan dengan hasil penelitian Wahyuningtyas (2015); Arifuddin dan Arrosyid (2017) yang memperoleh kesimpulan yaitu respon siswa terhadap penggunaan demonstrasi dengan alat peraga pada materi bilangan bulat sangat positif. Penggunaan metode dan media pembelajaran yang tepat memang sangat menunjang terhadap tercapainya keberhasilan siswa dalam proses pembelajaran. Hal ini menunjukkan bahwa keberhasilan pendididikan dalam setiap jenjang sangat ditunjang oleh adanya pendidik yang memiliki komitmen dan dedikasi yang tinggi (Arti, 2020).

\section{KESIMPULAN}

Berdasarkan hasil penelitian, metode demonstrasi membuat pelajaran menjadi lebih jelas, dapat mengatasi tipe belajar siswa yang berbeda-beda, menunjukkan adanya peningkatan aktifitas siswa dalam mengikuti proses pembelajaran, sehingga hasil belajar serta ketuntasan belajar siswa secara klasikal juga meningkat pada setiap siklusnya. Siklus I terlihat bahwa ketuntasan secara klasikal dengan nilai $\geq 65$ (KKM) mencapai 64\%, pada siklus II meningkat menjadi 92\%. Rata-rata hasil belajar juga mengalami peningkatan pada siklus I rata-rata 70.16 dan pada siklus II meningkat menjadi 89,20 . Hal ini menunjukkan adanya peningkatan hasil belajar siswa tentang materi operasi hitung bilangan bulat yang melibatkan bilangan negatif. Dengan demikian dapat disimpulkan bahwa melalui metode demonstrasi dengan media dapat meningkatkan pemahaman konsep siswa pada materi operasi hitung bilangan bulat.

\section{REKOMENDASI}

Rekomendasi dari penelitian ini adalah guru dapat memanfaatkan metode demonstrasi untuk diterapkan pada materi pelajaran yang lain, karena dengan menggunkan metode demontrasi pelajaran menjadi lebih jelas, dan lebih konkrit sehingga tidak terjadi verbalisme.

\section{UCAPAN TERIMAKASIH}

Terimakasih peneliti ucapkan kepada kepala SD Negeri 1 Tanjung Raya yang telah mengizinkan penelitian ini dilaksanakan. Selanjutnya ucapan terima kasih peneliti ucapkan kepada guru dan siswa kelas VI SD Negeri 1 Tanjung Raya yang telah mendukung terhadap pelaksanaan penelitian ini. 


\section{DAFTAR PUSTAKA}

Aprinawati, I. (2017). Peningkatan Hasil Belajar Matematika Materi Operasi Hitung Bilangan dengan Menggunakan Metode Demonstrasi Siswa Sekolah Dasar. Journal Cendikia: Jurnal Pendidikan Matematika, 1( 1): 54-67.

Arifuddin, A., \& Arrosyid, S. R. (2017). Pengaruh Metode Demonstrasi dengan Alat Peraga Jembatan Garis Bilangan Terhadap Hasil Belajar Matematika Materi Bilangan Bulat. Al Ibtida. Jurnal Pendidikan Guru M, 4(2): 165-178

Arti, E. S. (2020). Keterampilan Proses Calon Guru Pada Pembelajaran Sains Anak Usia Dini. Jurnal Wahana Pendidikan, 7(2): 135-138.

Eliana, N. (2016). Peningkatan Hasil Belajar Matematika Materi Operasi Penjumlahan Bilangan Bulat Melalui Permainan Lompat Henti. Jurnal Pendidikan Dasar, 1(7): 90-99.

Gunanto., \& Dhesy, A. (2018). ESPS ( Erlangga Straight Point Series) Matematika untuk SD/MI Kelas VI. Jakarta: Erlangga

Nurhaeni, N., Oyon, H.P., \& Resa, R. (2019). Pengaruh Media Kartu Bilangan Terhadap Pemahaman Siswa Mengenai Operasi Pengurangan Bilangan Bulat. Jurnal Pedadidaktika, 6(1); 58-67.

Pauziah, R. (2017). Penerapan Metode Diskusi Untuk Meningkatkan Aktifitas Siswa pada Pembelajaran Menirukan Pembacaan Pantun Anak di Kelas IV SD Negeri 19 Kepahiang Kabupaten Kepahiang Provinsi Bengkulu. Jurnal PGSD, 10(1): 42-46.

Praturan Mentri Pendidikan dan Kebudayaan Republik Indonesia Nomor 24 Tahun 2016 Tentang Kompetensi Inti dan Kompetensi Dasar Pelajaran pada Kurikulum 2013 pada Pendidikan Dasar.

Purnomo, Y. W. (2013). Bilangan Cacah dan Bulat. Bandung: Alpabeta.

Shoimin, A. (2014). 68 Model Pembelajaran Inovatif Dalam Kurikulum 2013. Jogjakarta: Ar-RUZZ Media.

Tantowi, H. (2013). Rancangan Alat Praga Perkalian dan Pembagian Bilangan Bulat. (online). Tersedia: http//hartantowi.blogspot.com/2013/07/rancangan-alat-peraga-pembelajaran.html?m=1 (3 Agustus 2020)

Wahyuningtyas, D. T. (2015) Penggunaan Media Mobil Mainan untuk Meningkatkan Pemahaman Konsep Operasi Hitung Bilangan Bulat. Jurnal Inspirasi Pendidikan, 5(1): 587-592

Wahyuningtyas, D. T. \& Iskandar, L. (2016) Meningkatkan Pemahaman Konsep Perkalian dan Pembagian Bilangan Bulat Menggunakan Media Wayangmatika. Jurnal Pancaran, 5(3): 51-60

Wardani, B. N. (2019) Meningkatkan Hasil Belajar Matematika Materi Operasi Hitung Bilangan Bulat dengan Teknik Formulasi pada Siswa Kelas VI SDN 2 Ketara Tahun Pelajaran 2018/2019 . Jurnal IImu Sosilal dan Pendidikan, 3(2): 290-298.

Wildaniati, Y. (2016) Pembelajaran Matematika Bilangan Bulat dengan Alat Peraga. Jurnal Elementary, 1(1): 33-40. 